From the Department of Surgery, College of Veterinary Medicine and

Small Animal Clinic MEVET, Helsinki, Finland.

\title{
The Use of Biodegradable Implants in the Fixation of Small Animal Cancellous Bone Fractures
}

\author{
By P. Axelson, J. Räihä, K. Sittnikow, K. Skutnabb, M. Mero, S. Vainionpää, \\ P. Törmälä and P. Rokkanen
}

\begin{abstract}
Axelson, P., J. Räihä, K. Sitnikow, K. Skutnabb, M. Mero, S Vainionpäa, P. Törmälä and P. Rokkanen: The use of biodegradable implants in the fixation of small animal cancellous bone fractures. Acta vet. scand. 1988, 29, 469-476. - In this study the cancellous bone fractures of $10 \mathrm{dogs}$ and 2 cats were surgically treated with biodegradable implants to fixate the fractures. The implants were made of selfreinforced PGA homopolymers. The patients were allowed to walk on their operated limbs immediately after the fixation and they started to use them within one week. All patients except one used their operated limbs without lameness in 6 weeks and the twelfth case in 8 weeks, due to a postoperative periosteal infection. Radiographically, the fractures of 10 patients healed in 6 weeks and in 12 weeks in 2 cases. No other pathological reactions in the bone could be seen in the radiographs than the periosteal infection. Because the implants resolved spontaneously there was no need for a second operation to remove them.
\end{abstract}

dog and cat; orthopaedics; traumatology.

\section{Introduction}

Although the surgical treatment of fractures by internal or external metallic devices has improved during the last few decades, this method still has some disadvantages.

The elasticity factor (Young's modul) of mental is 5-10 times greater than that of the bone (Tonino et al. 1976, Akeson et al. 1976, Paavolainen et al. 1978). If the metallic fixation implant is too rigid osteoporosis and decreased new bone formation will occur in the fracture site due to the lack of natural physical stimulation (micromotion) of the bone, which increases the risk of refracture after the removal of the implant (Brinker et al. 1984). Metallic implants will sometimes loosen before the fracture has healed, and infections around the implants have often been reported (Cochran et al. 1969, Uthoff \& Dubuc 1971, Slätis et al. 1987).

Professors Rokkanen and Törmälä and their team initiated researches to develop biodegradable implants for fracture fixations (Törmälä et al. 1984). The principal technique of making these implants is to meltmould or sinter poly-glycolic acid (PGA) fibres and a matrix of the same polymer under pressure at elevated temperatures into rodshaped implants (biorods) of different diameters and lengths (Biofix ${ }^{\mathbb{Q}}$ ).

The mechanical and chemical properties of these biorods were tested by Törmälä, Rokkanen and Vainionpää and their team. They showed that the initial flexural strength of the selfreinforced PGA biorod was about 20 
times greater than that of cancellous bone and was decreased to the same level in 4 weeks (Törmälä et al. 1984 and 1987).

The studies of the biodegradation and the bone compatibility of this biorod showed that the biodegradation started peripherically and was subsequently replaced by new bone. The surrounding bone tissue showed neither inflammation nor foreign body reaction (Vainionpää et al. 1986).

The first clinical study with these biorods was made by Rokkanen. Forty-four patients with displaced malleolar fractures, type Weber A or B were divided randomly into 2 groups. One was treated with conventional metallic implants and the other with biorods (Rokkanen et al. 1985).

Later on a similar study was made of Weber fractures of 56 patients with a follow up of at least 1 year. (Böstman et al. 1987). There were no differences in the healing processes between the 2 groups.

The first fracture fixation with this biodegradable implant in veterinary clinical surgery was performed by Axelson in 1986 (Axelson et al. 1988).

\section{Materials and methods}

The material in this study consisted of 10 dogs and 2 cats. They were ordinary clinical patients, each with a cancellous bone fractures presented to the clinics during a period of 1 year. fractures suitable for this study had to be simple and closed cancellous bone fractures not older than 2 days. $82 \%$ of the cancellous bone fracture cases came up to these requirements.

All the patients were under 1 year of age. The dogs had an average age of 5.5 months and the cats 4 months. The average weight of the dogs was $6.2 \mathrm{~kg}(1-12)$ and $1.5 \mathrm{~kg}$ (1-2) of the cats.

\section{Clinical findings}

The general condition of the patients was determined at their arrival to the clinic and their condition was normalized before surgery. All cases had a fourth degree (on the scale of 0-4) lameness of one limb. The site of the fractures were painful and swollen. Clinical instability could be found in all fractures.

\section{Radiographic findings}

All patients were radiographed in sedation. At least 2 radiographs were taken in 2 perpendicular directions (ant-post and med-lat). All fracture lines were clearly visible although only 1 fracture showed complete dislocation. The rest of the fractures were angulated or slightly dislocated.

\section{Diagnoses}

The following diagnoses were made on the basis of the clinical and the radiographic findings: A fractured lateral condyle of the distal humerous of $1 \mathrm{dog}$, a fractured olecranon of 1 cat, a supracondylar fracture of the distal femur of 1 dog and 1 cat with a proximal femoral fracture, a fractured proximal tibia of 6 dogs, a fractured calcanaeus of 1 dog and a fractured phalanx of 1 dog (Table $1)$.

The drills and the biodegradable implants (biorods) of suitable sizes were chosen on the basis of the previous radiographs (Biofix ${ }^{\circledR}$, Table 1).

\section{Surgery}

Operations were performed with a steril set of orthopedic instruments including drills of A-O standards. The biorods have the same diameters as the normal drills of A-O standards. A special instrument was utilized to insert the biorod into the drilled channel because the biorod would stick to the wall of the channel very quickly and it might split when hit by a hammer in an abaxial direction (Fig. 1). 
Table 1. The cases used in this study.

\begin{tabular}{cccrll}
\hline No. & Species & $\begin{array}{c}\text { Age } \\
(\mathrm{month})\end{array}$ & $\begin{array}{c}\text { Weight } \\
(\mathrm{kg})\end{array}$ & Implant & Diagnoses \\
\hline 1. & Dog & 8 & 5 & small & Fract. cond. lat. os hum. dx \\
2. & Cat & 7 & 2 & small & Fract. oleocrani sin. \\
3. & Dog & 8 & 12 & medium & Fract. supracond. os fem. dx. \\
4. & Cat & 1 & 1 & large & Fract. supracond. os fem. dx. \\
5. & Dog & 4 & 8 & medium & Fract. os tibiae prox. sin. \\
6. & Dog & 5 & 10 & large & Fract. os tibiae prox. dx. \\
7. & Dog & 6 & 4 & small & Fract. os tibiae prox. dx. \\
8. & Dog & 4 & 2 & small & Fract. os tibiae prox. dx. \\
9. & Dog & 6 & 1 & mini & Fract. os tibiae prox. dx. \\
10. & Dog & 5 & 8 & small & Fract. os calcanaei dx. \\
11. & Dog & 5 & 10 & mini & Fract. os phalangi I dig. 2 \\
12. & Dog & 4 & 2 & small & Fract. os tibiae prox. sin. \\
\hline
\end{tabular}

Sixes of Biofix ${ }^{(8)}$ :

Large: $\quad 4.5 \mathrm{~mm} \times 70 \mathrm{~mm}$

Medium: $4.5 \mathrm{~mm} \times 50 \mathrm{~mm}$

Small: $\quad 3.2 \mathrm{~mm} \times 50 \mathrm{~mm}$

Mini: $\quad 2.0 \mathrm{~mm} \times 30 \mathrm{~mm}$

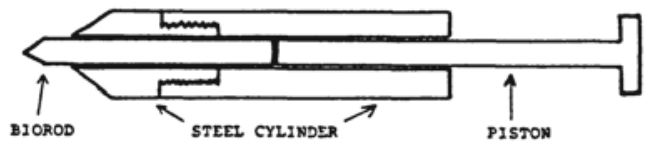

APPLICATOR

Figure 1. Schematic picture of the special instrument to insert the biorod into the channel.

The fractures were fixated after reducing the fragments. A channel was drilled crossing the fracture line in accordance with treatment standards for fracture fixation in small animal orthopaedics (Bojrab 1983, Brinker et al. 1983). Efforts were made to align the midpoint of the biorod in the fracture line to give equal support to both fragments. In 2 cases the fixation was secured with an osteosuture of PGA (Dexon ${ }^{\circledR}$; 2-USP) to neutralize muscular pull (Fig. 2 a and 3 a).

\section{Postoperative proceedings}

Postoperatively the operated limb was supported by a s. c. Robert Jones bandage with- out any splinting for 1 week. After this the patients were allowed to walk freely on their operated limbs.

Clinical and radiographic controls were made $1,3,6$ and 12 weeks after the operation. The clinical examination included the estimation of the lameness and the swelling (edema) of the operated area. The angulation and the dislocation of the fragments were evaluated from the radiographs. Furthermore, the fracture line, the callus formation, the bone radiodensity around the implant and the visibility of the drilled channel and the outlines of the implant were estimated from the radiographs. Possible signs of degenerative joint disease in the neighbouring joint(s) were recorded.

\section{Results}

\section{Clinical results}

All patients started to use their operated limbs during the first postoperative week. Within 6 weeks all patients except 1 could 

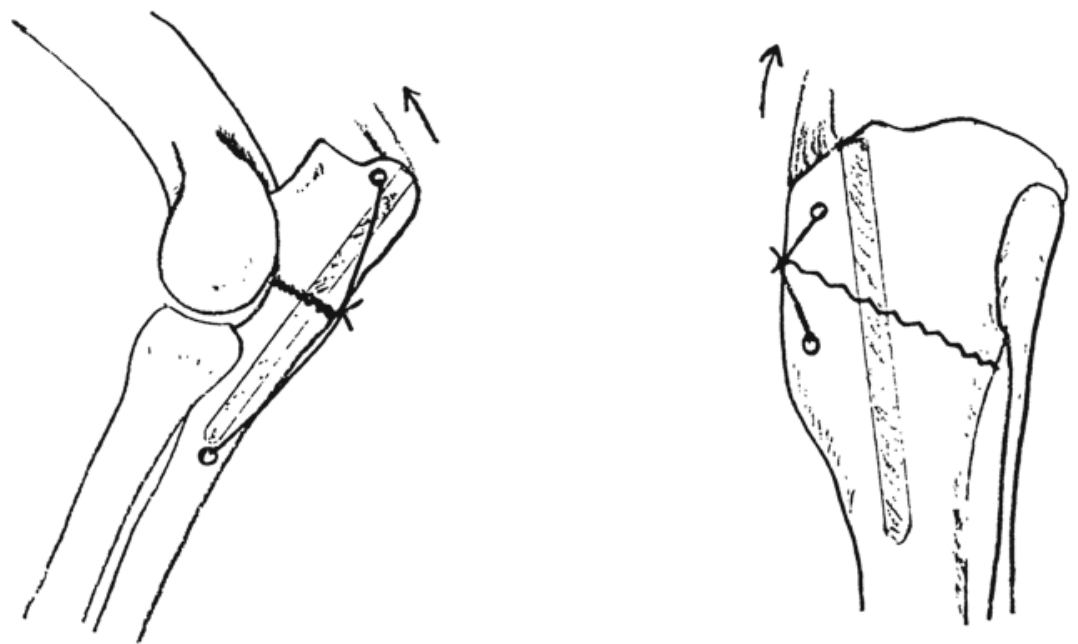

Figure 2. Schematic pictures of a fractured oleocranon of a cat (a) and a fractured proximal tibia of a $\operatorname{dog}(b)$.

walk without lameness and the fractures were clinically healed ( $92 \%)$. The edema of the operated area was gone within 6 weeks after surgery in $11 / 12$ patients $(92 \%)$. The twelft case, with a postoperative periosteal infection, showed no lameness after 8 weeks' treatment with antibiotics, but the swelling of the operated area was still prominent.

\section{Radiographic results}

Radiographically no angulation nor dislocation was seen between the fragments in $10 / 12$ cases $(83 \%)$. Two cases of proximal tibial fractures showed an angulation of 5-10 degrees between the fragments 3 weeks after the fixation. Radiographically the fracture lines disappeared in all cases between 6 and 12 weeks. Callus formation could be seen in all cases 3 weeks after the operation. The radiodensity of the bone surrounding the implants decreased during the first 3 weeks in $9 / 12$ patients (75\%) and increased in $10 / 12$ patients $(83 \%)$ even above normal bone radiodensity during the following 3 weeks. The occasional radiolucency of the drilled channels disappeared within 3 weeks. No other signs of pathological reactions in the fracture lines or in the surrounding bone tissue could be verified than the periosteal infection mentioned above. The radiographic healing of the fractures was apparent in 6 weeks in $9 / 12$ patients $(75 \%)$ and in 12 weeks in $3 / 12$ patients $(25 \%)$. No changes indicating secondary degenerative joint disease could be seen in the nearby joints.

\section{Discussion}

The postoperative evaluations were made as required in the Manual of Internal Fixation in Small Animals (Brinker et al. 1984). The fractures fixated in this study were all closed or simple ones with only 2 fragments to minimize the risk of secondary complications. this selection was considered to be necessary because the study was the first clinical application of biodegradable implants. The operative treatment followed the adaption technique described in the same manual with the difference that only selfreinforced PGA biodegradable rods (Biofix ${ }^{(B)}$ ) were used instead of nails and Kirschner wires made of metal.

The clinical results in this study agreed with those of similar fracture fixations made with 


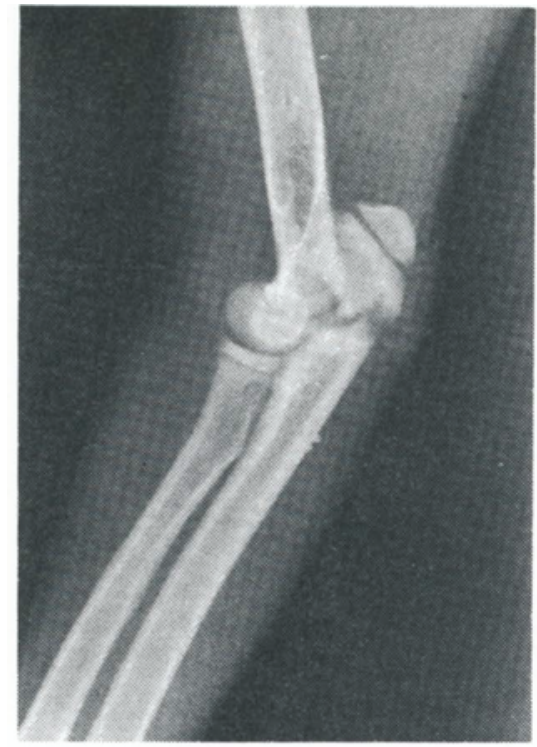

a

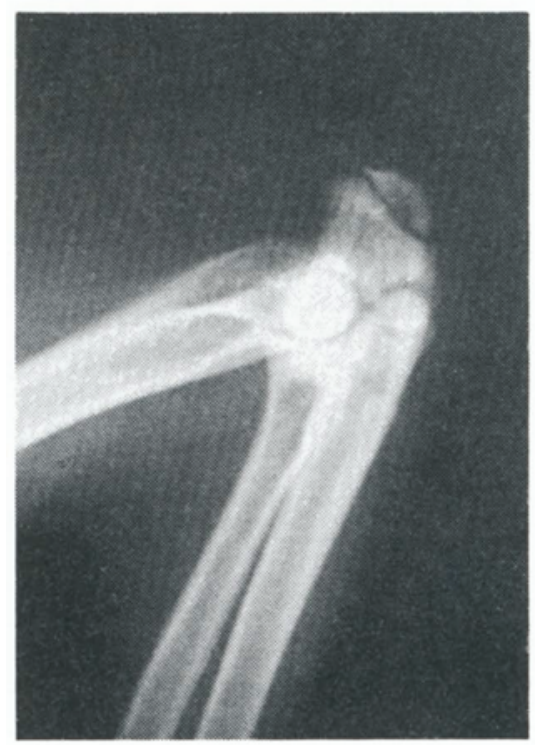

c

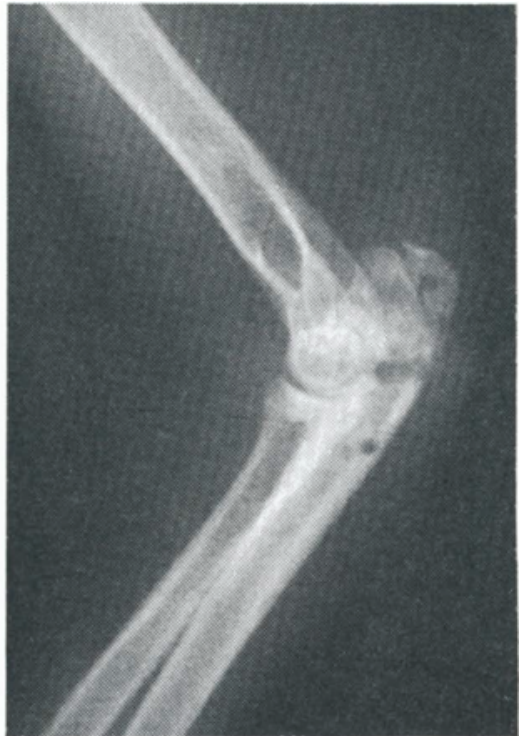

b

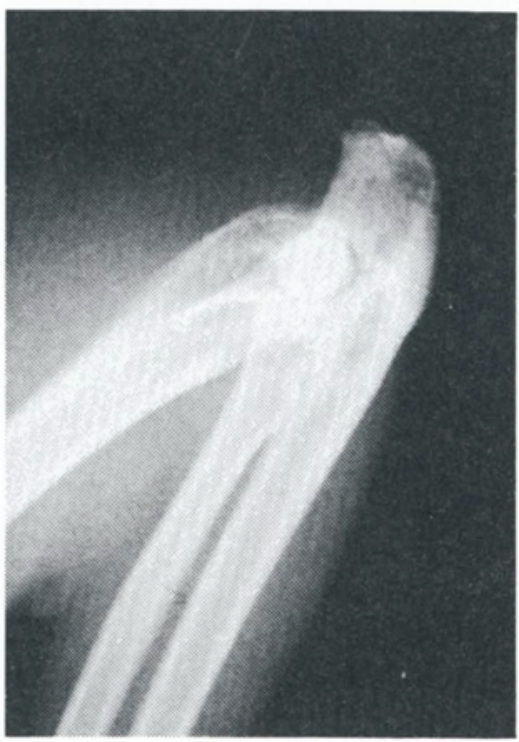

d

Figure 3. Radiographs of a fractured oleocranon of a cat, preoperative (a), third week control, note the holes of the osteosuture (b), sixth week control (c) and twelfth week control (d). 


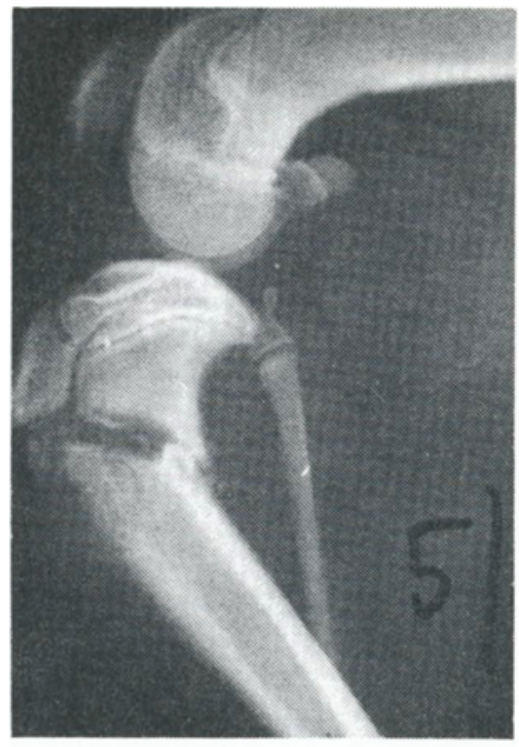

a

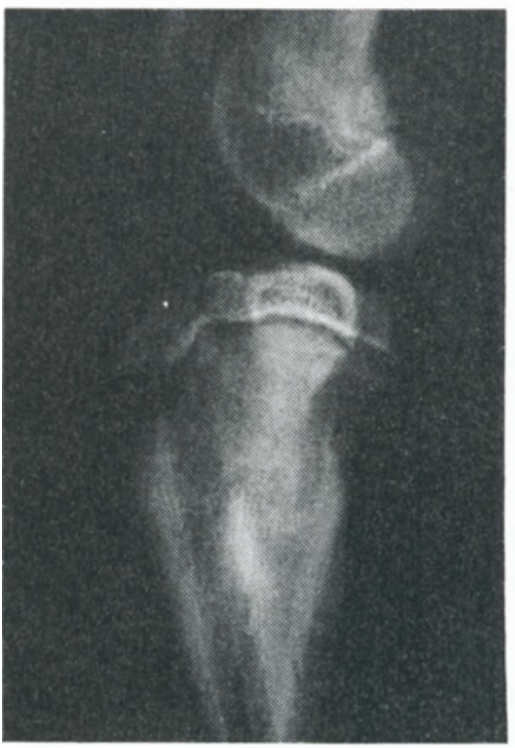

c

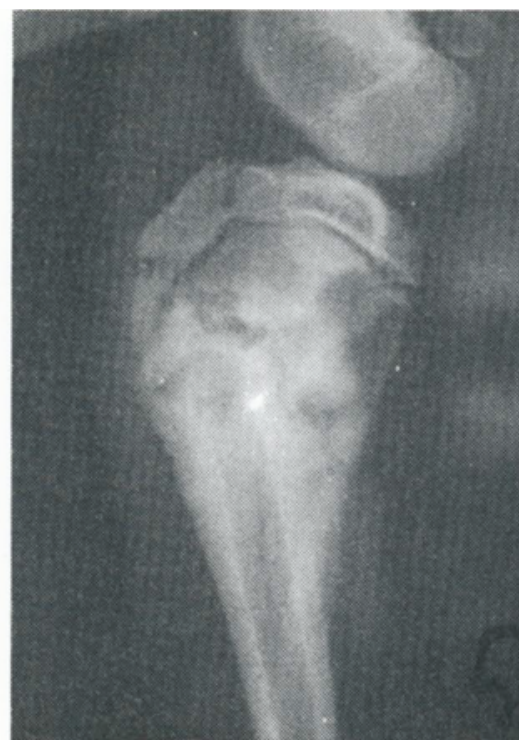

b

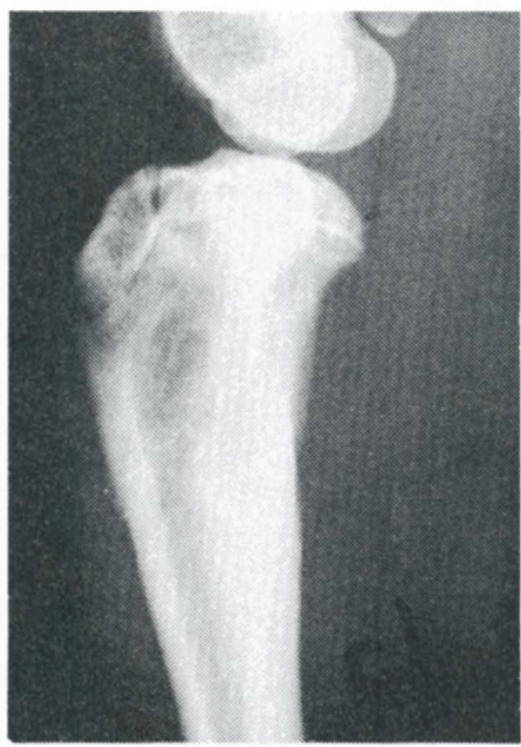

d

Figure 4. Radiographs of a fractured proximal tibia of a dog, preoperative (a), third week control (b), sixth week control (c) and twelfth week control (d). 
metal pins explained in the handbook of Small Animal Fractures (Brinker 1978).

Radiographically, the fractures healed by secondary bone union. The callus formation and the disappearance of the fracture lines were in accordance with the terms of secondary bone healing (Brown 1981). The biodegradable implants immobilized the fragments sufficiently not to cause delayed or nounion of the fractures (Hoefle 1981). Despite that they allow increasing micromovement to the fracture, which is beneficial to bone healing. This is due to the fact that the bending strength of the bone is equal to that of the biorods after four weeks in living tissue (Vainionpää 1987).

The advantage of this biodegradable implant fixation technique is that no secondary operation is needed to remove the implants as it is necessary when using metal implants (Brinker et al. 1984).

The use of biodegradable implants made of PGA is advisable in fractures which are supposed to be stable in 3 weeks and healed in 6 weeks, as in cancellous bone and physeal fractures. In diaphyseal fractures this device will biodegrade too quickly but the team led by Rokkanen and Törmälä has developed a new implant made of poly-lactic acid (PLA), which will last for 12 weeks in bone tissue. This device is made in the shape of an intramedullary nail and a screw. Experimental and clinical studies are being made of these PLA implants and the results will be presented in the near future.

In this selected material biodegradable implant fixation was equally useful as the metal implant method, but further studies are needed to specify the use of biorods in different cancellous bone fractures.

\section{Conclusions}

The biodegradable implants made of polyglycolic acid homoplymers (PGA) are sui- table for cancellous bone fracture fixations in young cats and dogs. The biodegradable implants used in this study met all the requirements of fracture fixation implants mentioned in the list made by Association for the Study of Internal Fixation (ASIF).

\section{References}

Axelson $P$, Räihä $J$, Mero $M$, Vainionpää $S$, Törmälä $S$, Rokkanen $P$ : The use of biodegradable implant in fracture fixation. A literature review and a report of two clinical cases. J. Small Anim. Pract. 1988, 29, 249-255.

Bojrab MJ: (ed.): Current techniques in small animal surgery 2 nd ed. Lea \& Febiger, Philadelphia 1983.

Brinker WO: Small Animal Fractures. Dept. of Continuing Education Services, Michigan State University, East Lansing, Mich. 1978.

Brinker WO, Hohn RB, Prieur WD: Manual of Internal Fixation in Small Animals. SpringerVerlag, Berlin, Heidelberg, New York, Tokyo 1984.

Brinker WO, Piermattei DL, Flo GL: Handbook of Small Animal Orthopedics and Fracture Treatment. W. B. Saunders Co., Philadelphia 1983.

Brown SG: Secondary Bone Union. In: Bojrab MJ (ed.) Pathophysiology in Small Animal Surgery. Lea \& Febiger, Philadelphia 1981, 528-533.

Böstman $O$, Vainionpää $S$, Hirvensalo E, Mäkelä $A$, Vihtonen $K$, Törmälä $P$, Rokkanen P: Biodegradable internal fixation for malleolar fractures. J. Bone J. Surg. 1987, 69-B, No. 4, 615.

Cochran GVB: Effects of internal fixation plates on mechanical deformation of bone. Surg. Forum 1969, 20, 469-471.

Hoefle WD: Delayed Union and Nonunion of Fractures. In: Bojrab, M. J. (ed.) Pathophysiology in Small Animal Surgery. Lea \& Febiger, Philadelphia 1981, 542-544.

Paavolainen P, Karaharju E, Slätis P, Ahonen J, Holmström T: Effect of rigid plate fixation on structure and mineral content of cortical bone. Clin. Orthop. 1978, 136, 287-293. 
Rokkanen $P$, Böstman $O$, Vainionpää $S$, Vihtonen $K$, Törmälä $P$, Laiho J, Kilpikari J, Tamminmäki $M$ : Biodegradable implants in fracture fixation: early results of treatment of fractures of the ankle. Lancet 1985, 14221424.

Slätis P, Karahurju E, Holmström, T, Ahonen J, Paavolainen P: Structural changes in intact bone after application of rigid plates with and without compression. J. Bone Jt. Surg. 1987, 60- $A, 516-522$.

Tonino AJ, Davidson DL, Klopper PJ, Linclau $L-A$ : Protection from stress in bone and its effects. J. Bone Jt. Surg. 1976, 58-B, 107-113.

Törmälä P, Rokkanen P, Kilpikari J, Pätiälä $H$, Vainionpää $S$, Vihtonen $K$, Mero M: Apparails chirurgicaux. Belgian Patent, 900 513, 1984.

Törmälä P, Vainionpää S, Kilpikari J, Rokkanen $P$ : The effects of fibre reinforcement and gold plating on the flexural and tensile strength of PGA/PLA copolymer materials in vitro. Biomaterials 1987, 8, 42.

Uthof HK, Dubuc FL: Bone structure changes in the dog under rigid internal fixation. Clin. Orthop. 1971, 81, 167-170.

Vainionpää S: Biodegradation of Polyglycolic Acid in Bone Tissue: An Experimental Study on Rabbits. Arch. Orthop. Trauma Surg. 1986, 104, 333-338.

Vainionpää $S$, Vihtonen $K$, Mero $M$, Pätiälä $H$, Rokkanen P, Kilpikari J, Törmälä P: Fixation of Experimental Osteotormies of the Distal Femur of Rabbits with Biodegradable Material. Arch. Orthop. Trauma Surg. 1986, 106, $1-4$.

Akeson WH, Woo SL-Y, Rutherford L, Coutts $R D$, Consalves $M$, Amiel $D$ : The effects of rigidity of internal fixation plates on long bone remodelling. Acta Orthop. Scand. 1976, 47, 241-249.

\begin{abstract}
Sammanfattning
Fixering av spongiösa benfrakturer hos hund och katt med hjälp av resorberbara implantater.

I dette kliniska arbete fixerades spongiösa benfrakturer med resorberbara implantater gjorda av polyglykolsyra hos 10 hundar och 2 katter. Patienterna fick omedelbart gå fritt på det opererade benet efter operationen. Alla patienter stödde på det opererade benet inom 1 vecka after operationen. Elva av de 12 patienterna var ohalta inom 6 veckor och den tolfte, som fått en sekundär periostal infektion under operationen var ohalt efter 8 veckor. Radiologiskt läkte frakturerna hos 10 patienter inpm 6 veckor och hos 2 patienter inom 12 veckor. Radiologiskt kunde inga patiologiska benreaktioner påvisas runt implantaten. Denna nye fixeringsmetod med resorberbara implantat visade sig vara användbar för behandling av spongiösa frakturer hos unge hundar och katter.
\end{abstract}

(Received January 8, 1988).

Reprints may be requested from: Per B. Axelson, Small Animal Clinic MEVET, Ulfsbyvägen 25, SF-00350 Helsingfors, Finland. 